\title{
BROILER FARMS PRACTICE WITHOUT AGP AS AN ISLAMIC CONCEPTIONIN THE STRATEGY TO ACHIEVE “ASUH” FOOD
}

\author{
Hafsan $^{1 *}$, Khaerani Kiramang ${ }^{2}$, Aminah Hajah Thaha ${ }^{2}$, Muhammad Rusdi Rasyid ${ }^{3}$ \\ ${ }^{1}$ Department of Biology, Universitas Islam Negeri Alauddin Makassar \\ H.M. Yasin Limpo Street No. 36, Gowa, South Sulawesi, Indonesia. 92113 \\ *Email: hafsan.bio@uin-alauddin.ac.id \\ 2Department of Animal Science, Universitas Islam Negeri Alauddin Makassar \\ H.M. Yasin Limpo Street No. 36, Gowa, South Sulawesi, Indonesia. 92113 \\ IIslamic Education Department, Postgraduate, IAIN Sorong \\ Sorong-Klamono Street Km. 17, Sorong, West Papua, Indonesia. 98417
}

\begin{abstract}
The use of Antibiotics Growth Promoters (AGP) was once reliance on Broiler farms that aim to improve immunity and trigger the growth of broiler. It turned out that AGP's use elicits a variety of very harmful impacts on human's health. The presence of residues of antibiotics in broiler meat will reduce the resistance of humans who consume them to some types of antibiotics even antibiotics that are prepared to handle the case of multi-resistant bacteria, namely the presence of antibiotic residues in broiler meat that will reduce the resistance of humans who consume them. So no longer impervious to some antibiotics, even antibiotics that are prepared to handle the case of multi-resistant bacteria. This case has become a limiting factor for the community, especially Muslims who are required to consume halal foods and bring benefits and do not contain harmful substances as admonitions in the Quran and hadith. This reality requires options to solve problems and answer real problems in people's lives wisely and contextually. Although AGP is required by the broiler but based on many research results, have shown that its role can be substituted with the addition of feed additives such as probiotics, enzymes and herbs as feed quality improvement efforts, including the implementation of biosecurity which must be carried out in an integrated manner. Broiler farms that implement good industry management have proved that broiler availability as a source of animal protein is Safe, Healthy, and Whole Halal (in the Indonesian acronym is ASUH) and has a broad market share. This context is by the conception of food safety in Islam, food safety from the Islamic normative context, namely balal and food safety from the health aspect, namely Thayyib. This paper responds to food safety, which has been a fidgetiness for all stratums of Muslim society. In contrast, the ASUH food source is one of the fulfilments of the main points of the Maqasid al-Shari'ab or the general objective stipulated in Islamic law, namely to realize goodness, provide benefits and avoid damage to humans.
\end{abstract}

Keywords: AGP, ASUH, broiler farms management, enzyme, herbs

\begin{abstract}
Abstrak: Penggunaan Antibiotic Growth Promoters (AGP) dulunya merupakan ketergantungan pada peternakan ayam pedaging yang bertujuan untuk meningkatkan kekebalan dan memicu pertumbuhan ayam pedaging. Ternyata penggunaan AGP menimbulkan berbagai dampak yang sangat merugikan bagi kesehatan manusia. Adanya residu antibiotik pada daging ayam pedaging akan menurunkan resistensi manusia yang mengkonsumsinya terhadap beberapa jenis antibiotik bahkan antibiotik yang disiapkan untuk menangani kasus bakteri multiresisten yaitu adanya residu antibiotik pada daging ayam pedaging yang akan mengurangi resistensi manusia yang mengkonsumsinya. Jadi tidak lagi kebal terhadap beberapa antibiotik, bahkan antibiotik yang disiapkan untuk menangani kasus bakteri multiresisten. Hal ini menjadi faktor pembatas bagi masyarakat khususnya umat Islam yang diwajibkan untuk mengkonsumsi makanan yang halal dan membawa manfaat serta tidak mengandung zat yang berbahaya sebagaimana peringatan dalam Al-Qur'an dan hadits. Realitas ini membutuhkan pilihan untuk memecahkan masalah dan menjawab masalah nyata dalam kehidupan masyarakat secara bijaksana dan kontekstual. Meskipun AGP dibutuhkan oleh ayam pedaging namun berdasarkan berbagai hasil penelitian, telah menunjukkan bahwa perannya dapat digantikan dengan penambahan feed additive seperti probiotik, enzim dan herbal sebagai upaya peningkatan kualitas pakan, termasuk penerapan biosekuriti yang harus dilakukan. Peternakan ayam pedaging yang menerapkan manajemen industri yang baik telah membuktikan ketersediaan ayam pedaging sebagai sumber protein hewani yang Aman, Sehat, dan Halal Utuh (dalam bahasa Indonesia singkatan ASUH) dan memiliki pangsa pasar yang luas. Konteks ini sesuai dengan konsepsi keamanan pangan dalam Islam, keamanan pangan dari konteks normatif Islam yaitu halal dan keamanan pangan dari aspek kesehatan yaitu Thayyib. Tulisan ini membahas terkait keamanan pangan, yang telah menjadi kegelisahan bagi semua lapisan masyarakat Muslim. Sebaliknya, sumber makanan ASUH merupakan salah satu pemenuhan poin utama dari Maqashid al-Syariah atau tujuan umum yang diatur dalam hukum Islam, yaitu mewujudkan kebaikan, memberikan manfaat dan menghindari kerusakan pada manusia.
\end{abstract}


Kata kunci: AGP, ASUH, manajemen peternakan ayam pedaging, enzim, herbal

\section{Introduction}

The Al-Qur'an has revealed many scientific signs as a method of exploring nature and life, including food, because of the critical role of food in maintaining life and supporting one's health. God set about eating in the Qur'an 27 times in various contexts and meanings. When talking about the food eaten (the object of the commandment), always emphasize one of the properties of halal (may) and thayyib (good) (Thabrani 2014; Nuraini 2018; Departemen Agama RI 2020). One of the explicit statements of the Qur'an in Surah An-Nisa which translates: "Then eat (the halal) as a delicious delicacy, again good in the end" (Q.S. an-Nisa': 4), explained that the recommended food is delicious and should have a favourable effect on eating (Departemen Agama RI 2020).

The halalness of food is an absolute requirement which the Qur'an always underlines. Besides, the Qur'an also requires that foods with thayyib nature. Therefore, the Qur'an explicitly forbids food if it can harm human health (Ali 2016; Andriyani 2019). This can be considered as a preventive step in the Islamic conception to protect human health from the harmful effects that these foods can cause. This further shows the existence of scientific signs of the Qur'an regarding halal and good food, considering that the Qur'an was revealed long before there was scientific evidence regarding the content of substances that can cause various kinds of diseases that are contained in foods. The (Nuraini 2018; Andriyani 2019).

Once the importance of food for life so that God governs the issue firmly in the Koran. To maintain the quality of food that the community will consume, all food industry players, including animal husbandry products, need to target to produce quality products. Quality animal food products are produced through a long and comprehensive process, including the origin of the ingredients and producing these materials. Producing animal food such as broiler is a comprehensive process from seed, feed and maintenance to post-harvest processes (Bolan et al., 2010; Sharma 2010; Sassi et al., 2016; Hakim et al., 2020).

Various factors determine productivity broiler as livestock commodities which have promising prospects. Chicks, feed, vaccines/drugs, vitamins as well as maintenance and labour environment are all factors that must be able to be managed well by the manufacturer to achieve maximum production yields (Bolan et al., 2010; Omar et al., 2012; Hussain et al., 2015). Feed as an essential factor in the broiler farming industry's success has become the focus of treatment to ensure broiler weight gain and benefit producers. The use of AGP in feed has been a long-term dependency by farmers. It aims to increase endurance and immunity, spur growth, and increase ration efficiency and increase production (Dibner \& Richards 2005).

On the other hand, their use can leave residues in stock rising products (Agyare et al., 2019; Lin et al., 2013) and a very harmful impact on humans, namely residual antibiotics in broiler meat will reduce the resistance of humans who consume them to some types of antibiotics that are prepared to handle cases of infectious diseases (Brown et al., 2017). Antibiotic resistance is a worldwide health threat. Antimicrobial resistance can be a serious problem if there are no global control efforts._Based on the survey results, it is known that at least 700,000 people die every year and it is estimated that by 2050 antimicrobial resistance will become the number 1 killer in the world, with a death rate reaching 10 million people per year (WHO, 2019).

Recognizing the many negative impacts caused by anti-microbial resistance, then since 2017, the World Health Organization (WHO) called on various parties such as the general public, health professionals, Government, farmers, veterinarians, food and feed industry to raise awareness of reducing the range of actions that can lead to anti-microbial resistance (WHO, 2017). Ban on the use of AGP in Indonesia through Permentan No. 14/2017 regarding the Classification of Veterinary Drugs, since 1 January 2018 the Government has banned AGP in the feed. This ban also strengthened by Permentan No. 22/2017 Registration and Circulation of feed, which requires the statement did not use the AGP in the formula feed produced for manufacturers who will register the feed. This condition further strengthens efforts to find alternative solutions for AGP through research, both at the government and university levels, to ensure food safety for the community (Direktorat Kesehatan Hewan, 2018). 
Alternatives to AGP use have been found through various studies that have been carried out, ranging from administering herbs, enzymes, essential oils, organic acids, and probiotic-prebiotic combinations. Feed supplementation with feed additive ingredients has been shown to increase feed efficiency, eliminate bacterial infections in the digestive tract to support maximum production results, accompanied by the implementation of standardized livestock management through consistent and comprehensive biosecurity, is the key to increasing broiler productivity which will ensure the availability of broiler meat as a safe, healthy, whole and Halal (in Indonesian: ASUH) source of animal protein so that it meets the conception of halal and Thai food (Omar et al., 2010).

Various studies have revealed alternative alternatives to growth supplements, including the provision of Phyto biotics (herbal ingredients that show a tendency to increase carcass weight and decrease the percentage of abdominal fat by administering Phyto biotics regularly every two days. (Kiramang et al., 2019). Application of probiotic Bacillus sp. in poultry showed a tendency to increase carcass weight and decrease abdominal fat percentage (Hidayat et al., 2016). The use of the prebiotic inulin of the Dahlia flower tuber (Dahlia variabilis) improved the carcass percentage value, chest percentage, and thigh percentage and reduced broiler abdominal fat content (Massolo et al., 2016). These studies show the great potential that can be developed with good results to replace AGP in poultry so that poultry meat with high nutritional value can be obtained and free from residues that are harmful to human health.

\section{The Halalan Thoyyiban Broiler Farm Production}

One of the efforts to increase broiler productivity depends on feed. The addition of antibiotics and growth hormone to poultry feed during the last 50 years has spread worldwide. The increasing number of cases of resistant anti-microbial antibiotics in various countries is a very worrying phenomenon. The possible development of resistant bacterial populations and the side effects of using antibiotics as AGP in livestock has resulted in banning AGP in livestock throughout the European Union and the United States since 1 January 2006. Meanwhile in Indonesia, the Government has officially banned the use of AGP since 1 January 2018.

The concept of Halalan Thayyiban in Islam is understood as Allah's command to consume halal and good food so that its implementation is part of syar'i commands and pious deeds. The concept of Halalan Thoyyiban within the framework of Maqasid Al-Sharia includes extensive aspects that must be discussed and reviewed holistically in order to fulfil the need for food that is Safe, Healthy, Whole and Halal (ASUH) for the Muslim community in particular and the public in general (Rosele et al., 2013). Concerning livestock products, this is in line with the Government's goals and responsibilities in ensuring food safety for consumers, not only for Muslims but also for the entire community (Alqudsi 2014; Farouk et al., 2014; Shahdan et al., 2016).

In interpreting the concept of Halalan Thayyiban in the livestock business, especially broilers, it realizes the implementation of governance that refers to the Maqashid Al-Sharia framework approach. The management of Broiler Farm business management which applies the Maqashid Al-Sharia system approach initiated by $\mathrm{Abu} \mathrm{Al}$ Maali $\mathrm{Al}$ Juwaini will regulate the entire production process at five maqashid levels, namely emergency (necessity), al-hajjah al'ammah (public need), al-makrumat (moral behaviour), al-mandubat (suggestions) and what is not stated in the nash (Wibowo, 2011). Likewise, the materials used in the production process are DOC, feed, tool materials as a production chain must refer to the concept of halalan thoyyiban to guarantee protection for human benefit (Omar \& Jaafar 2011; Alqudsi, 2014; Shahdan et al., 2016).

\section{Herbs and Applications as A Replacement For}

Herbs are additive phytogenic feed from plants that are added to animal feed to increase livestock productivity. Phytogenics are also classified as natural growth promoters or non-antibiotic growth promoters derived from herbs, spices and other plant parts that contain various active substances in each part of the plant. Herbal addition can be given in the form of plant parts in powder, granules or liquid (Hashemi \& Davoodi, 2012; Khattak et al., 2014; Dhama et al., 2015). 
Various studies have shown that herbs can increase the performance and productivity of broilers. However, further research still needs to be developed to obtain the level of effectiveness, optimal dosage, and each compound's workings in the herbs. The workings of each active compound contained in herbs are different, but in general, herbal administration can replace AGP as a natural antibiotic that is not harmful to livestock (Hashemi \& Davoodi 2012; Vinus et al., 2018). Herbs can also improve the digestive tract's performance, regulate the immune system, change digestive morphology, increase nutrient utilization, and increase livestock performance levels (Bozkurt et al., 2014; David et al., 2015; Giannenas et al., 2018). Herbs as phytogenic have shown that an anti-microbial, antioxidative, anticoccidial, provides an immunogenic effect in poultry feed. The addition of herbs in feed can also increase feed palatability, protect the oxidative damage of feed fats, improve digestibility and absorption of food substances in the digestive tract. Giving herbs also showed an increase in gastrointestinal function by decreasing the number of colonies of harmful bacteria, reducing fermentation, reducing digestive activity associated with the lymphatic system and high nutrient absorption in the caecal. Besides, some active herbal compounds can also increase mucus fluid production (Abbasnia et al., 2020).

Huang, Zhang, and Zhao (2009) reported Chinese herbal medicines: bupleurum, atractylodes, paeonia, glycyrrhiza, psoralea, mentha, poria and gypsum can be alternatives to antibiotics to reduce heat stress and promote growth in commercial livestock and poultry. Based on these results, Paeonia, glycyrrhiza, psoralea compounds containing phenol high where bioactive substances dissolved, being glycyrrhiza, Bupleurum and Paeonia contains levels of prebiotic higher. In contrast, the atractylodes, Paeonia, glycyrrhiza containing unsaturated fatty acids higher as it is known that the bioactive compounds in herbs have many benefits for livestock and poultry, likewise the prebiotic content and unsaturated fatty acids work together in increasing livestock productivity and can increase the body's defences of livestock and poultry.

\section{Enzymes and Applications as Substitute AGP}

Enzymes are substances that can be used as a substitute for Growth-hormone Antibiotics. Enzymes can increase the performance of feed digestion metabolism to increase feed efficiency and productivity of broilers and other livestock based on the results of research that has been conducted to test the ability of enzymes to improve broiler performance (Cowieson et al., 2006; Son \& Ravindran, 2012; Chotinsky, 2015; Amerah et al., 2015). Poultry feed ingredients are generally grains which are generally known to have anti-nutrients that can inhibit the absorption of feed nutrients. Addition of enzymes is a safe way to improve feed digestibility (Rutherfurd et al., 2007; Maqsood, 2013; Dosković et al., 2013; Moss et al., 2018).

The addition of enzymes in feed such as xylanase and glucanase is widely applied to nonruminant/monogastric due to the high fibre feed consumed to increase feed digestibility. (Amerah et al., 2012; Cowieson et al., 2010; Munyaka et al., 2016). However, the glucanase enzyme cannot solve the digestive problems and absorption of phosphate in monogastric, especially poultry. Therefore, the application of enzymes in poultry that is often added to feed is an enzyme that can increase poultry's productivity. It is a phytase. Phytase enzyme can break down the bonds between phosphate and phytic acid, which is a complex compound that binds phosphate, thereby reducing the availability of phosphate in the feed (Woyengo et al., 2010; Ptak et al., 2015; Hafsan et al., 2018; Konieczka et al., 2020).

Enzyme supplementation in poultry feed plays an essential role in increasing the availability of nutrients and slowing down the adverse effects of anti-nutritional substances contained in the feed. Several types of enzymes that are commonly added to poultry feed are: phytase works to hydrolyze the phytate in the ration; protease functions to hydrolyze protein; Xylanase works to hydrolyze xylan; pectinase works to break down pectin; lipase works to hydrolyze fat and other enzymes.

\section{Probiotic-Prebiotic Symbionts as AGP Replacement Solutions}

With the negative impact of the use of AGP, the researchers began looking for a replacement that is focused on natural ingredients, such as enzymes and herbs, including the use of microbial symbionts that use probiotics and prebiotics as additive materials substitute for antibiotics (Ghadban, 2002; Bagno 
et al., 2018; Mehdi et al., 2018). Probiotics are living microorganisms commonly form Lactic Acid Bacteria that may provide a health benefit to the host. Generally, probiotics can improve balance or restore intestinal flora. In poultry, the probiotic lactic acid bacteria were effective as an alternative to AGP (Manafi, 2015). Probiotics are feed additives in the form of beneficial live microbes, by improving the balance of microorganisms in the digestive tract (Mookiah et al., 2014; Mehdi et al., 2018; Siwek et al., 2018). Probiotic treatment has several objectives: to promote growth, improve feed digestibility, increase endurance, increase egg production, and improve beneficial microbes (Král et al., 2012; Saiyed et al., 2015; Dunislawska et al., 2017; Al-Khalaifa et al., 2019).

Meanwhile, prebiotics is feed ingredients in fibre that cannot be digested by monogastric livestock (poultry). This fibre can be a trigger for an increase in beneficial bacteria for livestock. Prebiotics are also known as nutrients suitable for good bacteria, but not suitable for less beneficial bacteria. In other words, prebiotics can increase the number of beneficial bacteria in the gut (Gibson, 1998; Kim et al., 2011; Cengiz et al., 2012; Wahyuni et al., 2019).

Exploring probiotics, prebiotics, and combining both as additive materials substitute for antibiotics in broiler chicken rations is exciting research and do not stop. The use of Starbio probiotics as much as 2.5 grams $/ \mathrm{kg}$ of ration provides better and efficient broiler chickens performance (Zainuddin et al., 2004). Mookiah et al. (2014) reported that $5 \mathrm{~g} / \mathrm{kg}$ IMO prebiotics, probiotics and their combination as a synbiotic were effective in improving broiler chickens' performance and increasing the beneficial bacteria and fatty acids. Some examples of commercial probiotic and prebiotic products include Temban, Biovet and Biolacta. The three examples of probiotics and prebiotics are available in liquid form and used for use through drinking water.

The working principle of probiotics are probiotic bacteria Lactobacillus and Bifidobacterium) work anaerobically produce lactic acid so that the digestive tract's $\mathrm{pH}$ down and hinder the development and growth of pathogenic bacteria. Probiotic bacteria inhabit the digestive mucosa, which also changes the composition of the bacteria present in the digestive tract. Other functions are maintaining the balance of the gastrointestinal microflora, suppressing the growth of pathogenic microbes by producing antimicrobial substances (bacteriocins), and increasing competitive exclusion (CE), namely the competitive mechanism between probiotics and pathogenic bacteria both on colony attachment and using nutrients (Neal-McKinney et al., 2012; Hegarty et al., 2016; Cremon et al., 2018).

\section{Implementation of Livestock Biosecurity as The Supporting Capacity of Non-AGP Broiler Farms}

Based on animal health, biosecurity is the first defence of disease prevention system against a variety of possible disease-causing microorganisms that are transmitted between animals and from animals to humans and vice versa to minimize negative impacts for society and the environment. The main components of biosecurity of concern consist of isolation measures, traffic control and sanitation. In pursuance of Thaha et al. (2018) There are several factors associated with the spread of pathogenic microorganisms internally, including the location of poultry farming, community behaviour or habits, public awareness, weak biosecurity, and poultry raising patterns. Meanwhile, the external influencing factors are livestock traffic, production facilities vehicles and erratic climate change.

Biosecurity consists of two words, namely bio, which means life and security, which means security or protection so that biosecurity can be interpreted as controlling or safeguarding living things. Based on an animal health perspective, biosecurity is the initial defence of a disease prevention system against various possible disease-causing microorganisms that are transmissible between livestock and animals to humans and vice versa to minimize negative impacts on society and the environment. Biosecurity aims to minimize disease causes, minimize the relationship between the disease agent and the host to minimize the level of environmental contamination by disease agents (FAO, 2003).

According to Buhman et al. (2007), the main components of biosecurity that are of concern when implementing it in the field consist of isolation measures, traffic control and sanitation. The application of 3-zone biosecurity is based on the lack of awareness of poultry farmers in maintaining hygiene sanitation in their farms, potentially spreading pathogenic microorganisms. If microorganisms' presence 
can be minimized, antibiotics in the feed as feed supplements and medication can be avoided. 3-zone biosecurity divides the livestock area into 3 (three) zones: red, yellow, and green. This division is a recommendation from the Ministry of Agriculture and FAO (The Food and Agriculture Organization), is to divide the farm into 3 (three) areas, of the area's dirtiest to cleanest area (cage). 3-Zone biosecurity is easy to implement because it does not require a large amount of money, so it is hoped that the breeders will start implementing this maintenance pattern. The application of biosecurity in its entirety can reduce the transmission of poultry disease and save production costs for the purchase of drugs, including antibiotics.

\section{Conclusion}

Alternative solutions to AGP have been found through various studies. Addition of herbs, enzymes and probiotic-prebiotic combinations have been shown to maintain broiler productivity. Feed supplementation with feed additive ingredients has been shown to increase feed efficiency and eliminate bacterial infections in the digestive tract to support maximum production results. Management, along with the implementation of standardized livestock management through consistent and comprehensive biosecurity, is the key to increasing broiler productivity which will ensure the availability of broiler meat as a safe, healthy, whole and Halal (ASUH) source of animal protein so that it meets the conception of halal and thayyib food.

\section{References}

Abbasnia, M., Mosleh, N., Dadras, H., Rezaeianzadeh, G., \& Boroomand, Z. 2020. Effect of Different Herbal Preparations on Experimental Viral Respiratory Complex of Broilers: Clinical, Pathological and Ciliary Activity Aspects. Journal of Herbmed Pharmacology, 9(3), 277-85.

Agyare, C., Boamah, V.E., Zumbi, C.N., \& Osei, F.B. 2019. Antibiotic Use in Poultry Production and Its Effects on Bacterial Resistance'. In Antimicrobial Resistance - A Global Threat, IntechOpen.

Al-Khalaifa. 2019. Effect of Dietary Probiotics and Prebiotics on the Performance of Broiler Chickens. Poultry Science, 98(10), 4465-79.

Ali, M. 2016. Konsep Makanan Halal Dalam Tinjauan Syariah Dan Tanggung Jawab Produk Atas Produsen Industri Halal. AHKAM : Jurnal Ilmu Syariah, 16(2), 291-306.

Alqudsi, S. G. 2014. Awareness and Demand for 100\% Halal Supply Chain Meat Products'. Procedia - Social and Behavioral Sciences, 130, 167-78.

Amerah, A. M. 2015. 'Interactions between Wheat Characteristics and Feed Enzyme Supplementation in Broiler Diets'. Animal Feed Science and Technology.

Amerah, A. M., K. Van De Belt., \& J. D. Van Der Klis. 2015. Effect of Different Levels of Rapeseed Meal and Sunflower Meal and Enzyme Combination on the Performance, Digesta Viscosity and Carcass Traits of Broiler Chickens Fed Wheat-Based Diets. Animal, 9(7), 1131-1137.

Amerah, A.M., G. Mathis, \& C.L. Hofacre. 2012. Effect of Xylanase and a Blend of Essential Oils on Performance and Salmonella Colonization of Broiler Chickens Challenged with Salmonella Heidelberg. Poultry Science, 91(4), 943-47.

Andriyani, A. 2019. Kajian Literatur Pada Makanan Dalam Perspektif Islam Dan Kesehatan. Jurnal Kedokteran dan Kesehatan, 15(2), 178-198.

Bagno, O. A., Prokhorov, O. N., Shevchenko, S. A., Shevchenko, A. I., \& Dyadichkina, T. V.2018. Use Of Phytobioticts In Farm Animal Feeding. Sel'skokhozyaistvennaya Biologiya, 53(4), 687-697.

Bolan, N.S., Szogi, A.A., Chuasavathi, T., Seshadri, B., Rothrock, M.J., \& Panneerselvam, P. 2010. Uses and Management of Poultry Litter. World's Poultry Science Journal, 66(4), 673-698.

Bozkurt, M., N Aysul., K._Küçükyilmaz., S.Aypak., G._Ege., A.U.Catli., H._Aksit., F.Cöven., K._Seyrek., \& M._Cinar. 2014. Efficacy of In-Feed Preparations of an Anticoccidial, Multienzyme, Prebiotic, Probiotic, and Herbal Essential Oil Mixture in Healthy and Eimeria Spp.-Infected Broilers. Poultry Science, 93(2), 389-399.

Brown, K., Uwiera, R.R.E., Kalmokoff, M.L., Brooks, S.P.J., \& Inglis, G.D. 2017. Anti-microbial Growth Promoter Use in Livestock: A Requirement to Understand Their Modes of Action to Develop Effective Alternatives. International Journal of Antimicrobial Agents, 49(1), 12-24.

Buhman., Marilyn., G. Dewell., \& D. D Griffin. 2007. Biosecurity Basics for Cattle Operations and Good Management Practices (GMP) for Controlling Infectious Diseases. Nebraska: University of Nebraska-Lincoln Extension.

Callaway, T.R., Edrington, T.S., Anderson, R.C., Harvey, R.B., Genovese, K.J., Kennedy, C.N., Venn, D.W., \& Nisbet, D.J. 2008. Probiotics, Prebiotics and Competitive Exclusion for Prophylaxis against Bacterial Disease. Animal Health Research Reviews, 9(2), 217-225.

Cengiz, Ö., Koksal, B.H., Koksal, O., Yagin, A., Bakirci, S., Beyaz, D., Buyukyoruk, S., \& Onol, A.G. 2012. Influence of Dietary Prebiotic Addition on Digestibility and Intestinal Microflora of Young Male Broiler Chickens Exposed to Delayed Feed Access after Hatch. International Journal of Poultry Science, 11(6), 408-416. 
Chotinsky, D. 2015. The Use of Enzymes to Improve Utilization of Nutrient in Poultry Diets. Bulgarian Journal of Agricultural Science, 21(2), 429-435.

Cowieson, A. J, M Hruby, and E. E. M Pierson. 2006. 'Evolving Enzyme Technology: Impact on Commercial Poultry Nutrition'. Nutrition Research Reviews.

Cowieson, A.J., M.R. Bedford., \& V. Ravindran. 2010. Interactions between Xylanase and Glucanase in Maize-Soy-Based Diets for Broilers. British Poultry Science, 51(2), 246-257.

Cremon, Cesare, Maria Raffaella Barbaro, Marco Ventura, and Giovanni Barbara. 2018. 'Pre- and Probiotic Overview'. Current Opinion in Pharmacology.

David, L.S., Vidanarachchi, J.K., Samarasinghe, K., Cyril, H.W., \& Dematawewa, C.M.B. 2015. Effects of Moringa Based Feed Additives on the Growth Performance and Carcass Quality of Broiler Chicken. Tropical Agricultural Research, 24(1), 1220.

Departemen Agama RI. 2020. Al Quran Dan Terjemahan. Jakarta: Departemen Agama RI.

Dhama, K., Latheef, S.K., Mani, S., Samad, H.A., Karthik, K., Tiwari, R., Khan, R.U., Alagawany, M., Farag, M.R., Alam, G.M., Laudadio, V., \& Tufarelli, V. 2015. Multiple Beneficial Applications and Modes of Action of Herbs in Poultry Health and Production-A Review. International Journal of Pharmacology, 11(3), 152-76.

Dibner, J.J., \& J.D. Richards. 2005. Antibiotic Growth Promoters in Agriculture: History and Mode of Action. Poultry Science, 84(4), 634-643.

Ditkeswan. 2019. Kementan dan FAO Dorong Peternak Unggas Terapkan Biosecurity 3 Zona. Kementerian Pertanian.

Dosković, V., Bogosavljević-Bosković, S., Pavlovski, Z., Milošević, Škrbić, Z., Rakonjac, S., \& Petričević, V. 2013. Enzymes in Broiler Diets with Special Reference to Protease. World's Poultry Science Journal, 69(2), 343-360.

Dunislawska, A., Slawinska, A., Stadnicka, K., Bednarczyk, M., Gulewicz, P., Jozefiak, D., \& Siwek, M. 2017. Synbiotics for Broiler Chickens - In Vitro Design and Evaluation of the Influence on Host and Selected Microbiota Populations Following in Ovo Delivery. PLoS ONE, 12(1), 1-20.

FAO. 2003. Biosecurity in Food and Agriculture. Report on the 17th Session of the committee on agriculture, Rome 31 March -4 April 2003.

. 2019. The State Of The World The State of Food and Agriculture 2019. Moving Forward on Food Loss and Waste Reduction.

Farouk, M.M., Al-Mazeedi, H.M., Sabow, A.B., Bekhit, A.E.D., Adeyemi, K.D., Sazili, A.Q., \& Ghani, A. 2014. Halal and Kosher Slaughter Methods and Meat Quality: A Review. Meat Science, 98(3), 505-519.

Ghadban, G. S. 2002. Probiotics in Broiler Production - A Review. Archiv fur Geflugelkunde. 66(2), 49-58.

Giannenas, I., E. Bonos», I. Skoufos., A. Tzora., I. Stylianaki., D. Lazari., A. Tsinas ., E. Christaki., \& P. Florou-Paneri . 2018. Effect of Herbal Feed Additives on Performance Parameters, Intestinal Microbiota, Intestinal Morphology and Meat Lipid Oxidation of Broiler Chickens. British Poultry Science. 59(5), 545-553.

Hafsan, H., N. Nurjannah., C. Muthiadin., I.R. Azis., A. Ahmad., L. Agustina., \& A. Nasir. 2018. 'Phytate Activity Of Thermophilic Bacteria From Sulili Hot Springs In Pinrang District South Sulawesi'. Scripta Biologica (36): 1-4.

Hakim., L. Idris, N. Mahiza Md. Isa., S. M. Tahir., \& E. B. Ibitoye. 2020. Effect of Halal and Non-Halal Slaughtering Methods on Bacterial Contamination of Poultry Meat. Sains Malaysiana, 49(08), 1947-50.

Hashemi, S. R., \& H. Davoodi. 2012a. Herbal Plants as New Lmmuno-Stimulator 1n Poultry Industry: A Review. Asian Journal of Animal and Veterinary Advances, 7(2), 105-116.

Hegarty, J.W., C. M. Guinane., R. P. Ross., C. Hill., \& P. D. Cotter. 2016. Bacteriocin Production: A Relatively Unharnessed Probiotic Trait? F1000Research, 5(2587), 1-9.

Hidayat., M. Nur, R. Malaka., L. Agustina., \& W. Pakiding. 2016. Abdominal Fat Percentage and Carcass Quality of Broiler Given Probiotics Bacillus Spp. Scientific Research Journal, IV(X): 33-37.

Huang., Xiaodong., J. Zhang., \& Z. Zhao. 2009. Chinese Medicinal Composition for Prevention and Control of Infectious Diseases of Poultry and Livestock, and the Preparation Method and Application Thereof. Faming Zhuanli Shenqing.

Hussain, J., I. Rabbani., S. Aslam., \& H.A. Ahmad. 2015. An Overview of Poultry Industry in Pakistan'. World's Poultry Science Journal, 71(4), 689-700.

Jadhav, K., K.S. Sharma., S. Katoch., VK Sharma., \& B.G. Mane. 2015. 'Probiotics in Broiler Poultry Feeds: A Review'. Journal of Animal Nutrition and Physiology, 1, 4-16.

Khattak, F., A. Ronchi, P. Castelli., \& N. Sparks. 2014. Effects of Natural Blend of Essential Oil on Growth Performance, Blood Biochemistry, Cecal Morphology, and Carcass Quality of Broiler Chickens. Poultry Science, 93(1), $132-37$.

Kim, G. B., Y. M. Seo., C. H. Kim., \& I. K. Paik. 2011. Effect of Dietary Prebiotic Supplementation on the Performance, Intestinal Microflora, and Immune Response of Broilers. Poultry Science, 90(1), 75-82.

Khaerani, K., M. N. Hidayat, A. Anas, A. H. Thaha., Hafsan" \& R. Mappanganro. 2019. Effectivity of Liquid Herbal and Supplemented Frequency on the Body Weight Percentage of the Carcass and Abdominal Fat of Broilers. In IOP Conference Series: Earth and Environmental Science, 247, 1-8.

Konieczka, P., S.A._Kaczmarek., M._Hejdysz., M._Kinsner., D._Szkopek., \& S._Smulikowska. 2020. Effects of Faba Bean Extrusion and Phytase Supplementation on Performance, Phosphorus and Nitrogen Retention, and Gut Microbiota Activity in Broilers. Journal of the Science of Food and Agriculture, 100(11), 4217-4225.

Král, M., M. Angelovi., \& L' Mrázová. 2012. Application of Probiotics in Poultry Production. Animal Science and Biotechnologies, 45(1), 55-57.

Lin, J., A._A.Hunkapiller., A._C.Layton., Y-J.Chang., \& K.R Robbins. 2013. Response of Intestinal Microbiota to Antibiotic Growth Promoters in Chickens. Foodborne Pathogens and Disease, 10(4): 331-37. 
Manafi, M. 2015. Comparison Study of a Natural Non-Antibiotic Growth Promoter and a Commercial Probiotic on Growth Performance, Immune Response and Biochemical Parameters of Broiler Chicks. Journal of Poultry Science, 52(4), 274281.

Maqsood, K. 2013. A Review on Role of Exogenous Enzyme Supplementation in Poultry production. Emirates Journal of Food and Agriculture, 25(1): 66-80.

Massolo, R., A. Mujnisa., \& L. Agustina. 2016. Persentase Karkas Dan Lemak Abdomial Broiler Yang Diberi Prebiotik Inulin Umbi Bunga Dahlia (Dablia variabilis). Buletin Nutrisi dan Makanan ternak, 12(2), 50-58.

Mehdi, Y., M-P. Lètourneau-Montminy, M-L. Gaucher., Y. Chorfi., G. Suresh., T. Rouissi., S. K. Brar., C. Cote., A. A. Ramirez., \& S. Godbout. 2018. Use of Antibiotics in Broiler Production: Global Impacts and Alternatives. Animal Nutrition, 4(2), 170-178.

Mookiah, S., C._C. Sieo., K._Ramasamy., N._Abdullah., \& Y.W._Ho. 2014. Effects of Dietary Prebiotics, Probiotic and Synbiotics on Performance, Caecal Bacterial Populations and Caecal Fermentation Concentrations of Broiler Chickens. Journal of the Science of Food and Agriculture 94(2): 341-48.

Moss, A.F., P.V. Chrystal., Y. Dersjant-Li., P.H. Selle., \& S.Y. Liu. 2018. Responses in Digestibilities of Macro-Minerals, Trace Minerals and Amino Acids Generated by Exogenous Phytase and Xylanase in Canola Meal Diets Offered to Broiler Chickens. Animal Feed Science and Technology, 240, 22-30.

Munyaka, P.M., N.K. Nandha., E. Kiarie., C.M. Nyachoti., E. Khafipour. 2016. Impact of Combined $\beta$-Glucanase and Xylanase Enzymes on Growth Performance, Nutrients Utilization and Gut Microbiota in Broiler Chickens Fed Corn or Wheat-Based Diets. Poultry Science, 95(3), 528-540.

Neal-McKinney, J.M., X. Lu., T. Duong., C.L. Larson., D.R. Call., D.H. Shah., \& M.E. Konkel. 2012. Production of Organic Acids by Probiotic Lactobacilli Can Be Used to Reduce Pathogen Load in Poultry'. PLoS ONE, 7(9), 1-11.

Nuraini, N. 2018. Halalan Thayyiban Alternatif Qurani Untuk Hidup Sehat. Jurnal Ilmiah Al-Mu'ashirah 15(1): 82-93.

Omar, E.N., \& H.S. Jaafar. 2011. Halal Supply Chain in the Food Industry - A Conceptual Model. In 2011 IEEE Symposium on Business, Engineering and Industrial Applications (ISBELA), IEEE, 384-89.

Omar, E. N., H.S. Jaafar., \& M. R. Osman. 2010. Halal Supply Chain: A Preliminary Study of Poultry Industry. Advances in Business Research International Journal, 98-102

. 2012. Assessing Halalan-Toyyiban Food Supply Chain in the Poultry Industry. International Halal Conference 2012 (INHAC). Malaysia, 4-5 September 2020.

Périchon, B., P. Courvalin., \& C.W. Stratton. 2015. Antibiotic Resistance. In Reference Module in Biomedical Sciences, Elsevier.

Ptak, A., M.R. Bedford., S. Świątkiewicz., K. Żyła., \& D. Józefiak. 2015. Phytase Modulates Ileal Microbiota and Enhances Growth Performance of the Broiler Chickens' ed. Shu-Biao Wu. PLOS ONE, 10(3), e0119770, 1-15.

Putri, A. W. 2019. “Biosekuriti 3-Zona: Solusi Bisnis Peternakan Unggas Di Indonesia.” Tirto.id. June 19.

Rosele, M.I., S.M. Syed Jaafar., \& M.A. Ramli. 2013. Prinsip-Prinsip Halal dan Haram Menurut Yusuf Al-Qaradawi. Halalan Thoyyiban Perspektif Malaysia.

Rutherfurd, S.M., T.K. Chung., \& P.J. Moughan. 2007. The Effect of a Commercial Enzyme Preparation on Apparent Metabolizable Energy, the True Ileal Amino Acid Digestibility, and Endogenous Ileal Lysine Losses in Broiler Chickens. Poultry Science, 86(4), 665-72.

Saiyed, M.A., R. S. Joshi., F. P. Savaliya., A. B. Patel., R. K. Mishra., \& N. J. Bhagora. 2015. Study on Inclusion of Probiotic, Prebiotic and Its Combination in Broiler Diet and Their Effect on Carcass Characteristics and Economics of Commercial Broilers'. Veterinary World, 8(2), 225-231.

Saputro, F. A. 2017. "Manfaat Penggunaan Biosekuriti Tiga Zona Di Peternakan.” Republika.co.id. November 07.

Sassi, N. B., X. Averós., \& I. Estevez. 2016. Technology and Poultry Welfare. Animals, 6(10), 62, 1-21.

Shahdan, I. A., J. M. Regenstein., A. S.M. Shahabuddin., \& M. T. Rahman. 2016. Developing Control Points for Halal Slaughtering of Poultry. Poultry Science, 95(7), 1680-1692.

Sharma, B. 2010. Poultry Production, Management and Bio-Security Measures. Journal of Agriculture and Environment, 11, 120125.

Siwek, M., A. Slawinska., K. Stadnicka., J. Bogucka ., A. Dunislawska., \& M. Bednarczyk. 2018. Prebiotics and Synbiotics in Ovo Delivery for Improved Lifespan Condition in Chicken'. BMC Veterinary Research, 14(1), 402, 1-17.

Son, J-H., \& V. Ravindran. 2012. Feed Enzyme Technology: Present Status and Future Developments. Recent Patents on Food, Nutrition \& Agriculture, 3(2), 102-109.

Thabrani, A. M. 2014. Esensi Ta'abbud Dalam Konsumsi Pangan (Telaah Kontemplatif Atas Makna Halâl-Thayyib). ALIHKAM: Jurnal Hukum \& Pranata Sosial, 8(1), 55-68.

Thaha, A.H., J. Rauf., \& I. Bagenda. 2018. Peta Penyebaran Virus Avian Influenza Pada Unggas Di Kabupaten Polewali Mandar Tahun 2008-2013. Jurnal Riset Veteriner Indonesia, 2(1), 19-26.

Vinus, R.D., N. Sheoran., N Maan., \& B Tewatia. 2018. Potential Benefits of Herbal Supplements in Poultry Feed: A Review'. Pharma Innov, 7(6), 651-656.

Wahyuni, S., A. S. Agustina., H. Natsir., \& I. Raya. 2019. The Prebiotic Production by Using Cassava Peels with the Addition of Both $\mathrm{K}+$ and $\mathrm{Mg} 2+$ Metal Ions as an Activator and Their Potential to Enhance Broiler Quality. Journal of Physics: Conference Series, 1341(3), 1-7.

WHO. 2019. No Time to Wait: Securing the Future from Drug-Resistant Infections. Artforum International.

WHO. 2017. World Health Organization Global Action Plan on Antimicrobial Resistance.

Wibowo, A. 2011. Maqoshid Asy Syariah : The Ultimate Objective of Syariah. Islamic Finance. 
Widyantara, P.R.A., I.K.A. Wiyana., \& N.P. Sarini. 2013. Tingkat Penerapan Biosekuriti Pada Peternakan Ayam Pedaging Kemitraan Di Kabupaten Tabanan Dan Gianyar. Peternakan Tropika, 1(1), 45-57.

Woyengo, T.A., B.A. Slominski., \& R.O. Jones. 2010. Growth Performance and Nutrient Utilization of Broiler Chickens Fed Diets Supplemented with Phytase Alone or in Combination with Citric Acid and Multicarbohydrase. Poultry Science, 89(10), 2221-29.

Zainuddin, D., K. Diwyanto., \& Suharto (Suharto). 2004. Utilization of A Probiotic "Starbio" in Broiler Diet with Different Levels of Crude Fibre. Buletin Peternakan, Special Edition, 171-177. 